In addition to his textbook in public administration, Bob authored two other books: The Bureaucratic State: An Annotated Bibliography, and, with Peter Longo, The Nebraska Constitution: A Reference Guide. He edited and coedited three others. The range and depth of Bob's intellect, his skill in fashioning an argument, his ability to turn a phrase, and his motivation to link public administration to core values are reflected in his essay "On Teaching Public Personnel Administration: A Weberian Perspective."

In it, he calls upon political science to make its courses more relevant to students and asks what could be more relevant than public personnel administration in as much as most, if not, all of our students will wind up as personnel somewhere. Yet, he points out, one is hard pressed to find in introductory texts more than a discussion of technique when it comes to personnel administration. But, he asks, will the drive for improved and better technique and their contribution to rational human control engage students. Not likely. He calls for a fresh perspective moving beyond technique. $\mathrm{He}$ suggests one provided by Weber. Weber's lesson for the teacher of public personnel administration is to remind students that, no matter how imposing a particular technique may be, he/she has the right to ask "What is this all about?" "In the bluntest terms, if one, in the course of his/her organizational life, runs across a practice which appears to be a rotten trick, then it might very well be just that." Ultimately, the issue is one of meaning. Public personnel administration can help students grapple with the problem of meaning, in a context where they are likely to find themselves.

Bob involved himself in community affairs, chairing the Charter Revision Commission for the City of Lincoln and serving as a consultant to the State Constitutional Revision Commission for the State of $\mathrm{Ne}$ braska. Bob also did more than his share of university and department related service. Bob always seemed available for many of the jobs no one else wanted. He served as liaison to the library ensuring that the books and journals faculty wanted were purchased by the library, super- vised student interns, chaired the promotion and tenure committee, and yes, did grade appeals. We knew he did a lot. Just how much, we are still finding out.

Bob, as we used to joke with him, could have been a contender, a dean, provost, perhaps a president of a college or university. But what he wanted was to teach and do it well. He did. He will be missed by his students and colleagues.

Bob is survived by his lovely wife Erika, daughter Christiana, and son Tom.

John Comer

University of Nebraska, Lincoln

Peter Longo

University of Nebraska, Kearney

\section{Edward S. T. Su}

Edward S. T. Su died November 10, 1997, after an extended illness. He was 76 years old. Dr. Su taught political science at Texas A\&I University (now Texas A\&M UniversityKingsville) from 1967 until he retired as a full professor, in 1989.

Su was born in Anhui, China (mainland). He received a law degree from National Anhwei University in China in 1944. He later emigrated from China and became a naturalized United States citizen. He earned a bachelor's degree in political science and criminology from Fresno State College between 1948 and 1950. From 1950-55, he attended the University of Illinois, Champaign-Urbana, where he earned two masters degrees (political science and library science), and began work toward the Ph. D. Su resumed work on the doctorate at Fordham University, in 1958, and was awarded the degree from Fordham, in 1962. His doctorate was in political science with a specialization in international relations.

Dr. Su served from 1944-1947 as an instructor: first, at the Central Police University in Nanking, China, and then at National Anhwei University. In the U.S., he held positions at Pennsylvania State University (cataloger, 1955-57), Rocky Mountain College (assistant professor, political science, 1962-64), Dickinson [North Dakota] State College, 1965-
66, Lake Superior State College (political science professor and library director, 1966-67), and at Texas A\&I, 1967-89.

At Texas A\&I, Su taught United States and Texas government as well as international politics, international law and organizations, politics of China, politics of the Soviet Union, and the politics of Southeast Asia. His publications, mostly in the 1960s, dealt with various aspects of Sino-Soviet Relations. Dr. Su belonged to several professional organizations. Besides the American Political Science Association, he held memberships in the American Academy of Political and Social Science, the International Political Science Association, the International Studies Association, and the Association of Asian Studies. Su was listed in a variety of Who's Who publications in the $1970 \mathrm{~s}$.

Although Dr. Su's personal experience included expropriation of the family business by the Communist government, his perspective on the accomplishments and limitations of the Communist regime was always judicious and well balanced. Su traveled extensively in China once this was allowed. After retirement, he worked on a book on contemporary China, but competing demands and ill health prevented him from finishing it. He had considerable insight concerning how China could blend a healthy degree of modernization and democratization with retention of important elements of traditional Chinese culture and customs.

Dr. Su was a dedicated teacher who encouraged students to take their concerns about international issues beyond the classroom. From 1967 until the mid-1980s, he sponsored a student organization, the International Relations Club. The club, which sometimes had eighty or more members, sponsored informational forums on a variety of international topics, often addressing the immediate concerns of international students at the university. Su was a serious and capable scholar, a model of collegiality and dedication in the political science department, and a valued member of the university community.

Dr. Su's given name, Guang Ping, means "try to help the poor people." 
This is most fitting, as he always sought to help those in need. Over the years, Dr. Su personally sponsored more than 50 students from China, Hong Kong, and Taiwan to come to the US for their college education at Texas A\&M-Kingsville or
Texas A\&M-College Station. He also assumed major responsibility for providing personal and financial assistance and guidance to a large extended family that remained in China. His wife, Lisa $\mathrm{Zhu}-\mathrm{Su}$; a daughter,
Deborah Su-Edwards of Arlington, Texas; two sons, Francis Su of Claremont, California, and David Su of Kingsville; and a sister, Ji Fan Su of China, survive Dr. Su.

J. D. Phaup

Texas A\&M University-Kingsville 